\title{
Griseofulvin, Diketopiperazines and Cytochalasins from Endophytic Fungi Colletotrichum crassipes and Xylaria sp., and Their Antifungal, Antioxidant and Anticholinesterase Activities
}

\author{
Vanessa M. Chapla, ${ }^{a, b}$ Maria L. Zeraik, ${ }^{a, c}$ Mariana C. Cafeu, ${ }^{a}$ Geraldo H. Silva, ${ }^{d}$ \\ Alberto J. Cavalheiro, ${ }^{a}$ Vanderlan S. Bolzani, ${ }^{a}$ Maria C. M. Young, ${ }^{e}$ Ludwig H. Pfenning $f$ \\ and Angela R. Araujo*,a \\ ${ }^{a}$ Núcleo de Bioensaios, Biossíntese e Ecofisiologia de Produtos Naturais (NuBBE), Instituto de Química, \\ Universidade Estadual Paulista (Unesp), 14800-900 Araraquara-SP, Brazil \\ ${ }^{b}$ Curso de Química Ambiental, Universidade Federal do Tocantins (UFT), 77402-970 Gurupi-TO, Brazil \\ ${ }^{c}$ Laboratório de Fitoquímica e Biomoléculas (LabFitoBio), Departamento de Química, \\ Universidade Estadual de Londrina (UEL), 86051-990 Londrina-PR, Brazil \\ ${ }^{d}$ Instituto de Ciências Exatas e Tecnológicas, Universidade Federal de Viçosa, \\ 38810-000 Rio Paranaíba-MG, Brazil
}

${ }^{e}$ Seção de Fisiologia e Bioquímica de Plantas, Instituto de Botânica, 01061-970 São Paulo-SP, Brazil

${ }^{f}$ Departamento de Fitopatologia, Universidade Federal de Lavras, 37200-000 Lavras-MG, Brazil

\begin{abstract}
One new natural product, 1-phenylethyl- $O$ - $\alpha$ - $L$-rhamnopyranoside, together with eight known diketopiperazines and two benzene derivatives were isolated from the endophytic fungus Colletotrichum crassipes, whereas six known compounds including two griseofulvins, three cytochalasins and one dihydroisocoumarin were produced from the endophyte Xylaria sp., both endophytic fungi are associated with leaves of Casearia sylvestris. Cyclo $(D)$-Pro- $(D)$-Phe, $\mathrm{N}$-(2-phenylethyl)acetamide and 5-carboxy-6-hydroxy-3-methyl-3,4-dihydroisocoumarin exhibited potent antifungal activity against Cladosporium cladosporioides and $C$. sphaerospermum. The compounds cyclo $(D)$-Pro- $(D)$-Phe, griseofulvin, cytochalasin B and cytochalasin D exhibited antioxidant activity, and the compounds cyclo $(D)$-Pro- $(D)$-Phe, cytochalasin B and cytochalasin C showed potent acetylcholinesterase (AChE) inhibition. In addition, this is the first report on the isolation of secondary metabolites from two endophytic fungal strains, associated with Casearia sylvestris.
\end{abstract}

Keywords: endophytic fungi, Casearia sylvestris, Colletotrichum crassipes, Xylaria sp., biological activity

\section{Introduction}

Casearia genus (Salicaceae) is found particularly in tropical and subtropical regions. This genus has more than 160 described species, seventy of which belong to the American continent, and thirty-seven are present in Brazil. Casearia sylvestris Sw. is popularly known as "guaçatonga" and is used in traditional medicine to treat several pathologic processes such as inflammation, skin lesions and microbial infections. This species also shows anti-inflammatory, antimicrobial and anti-ulcer

*e-mail: araujoar@iq.unesp.br properties. ${ }^{1,2}$ In our continuous search for chemically new and biologically potent metabolites produced by endophytic fungi associated with the species of the Brazilian plant, C. sylvestris was subjected to endophytes isolation and five endophytic fungi were obtained. Colletotrichum crassipes and Xylaria sp. fungi were isolated for the first time from the leaves of $C$. sylvestris.

The Xylaria genus is the largest genus of the family Xylariaceae and includes 300 accepted species of stromatic pyrenomycetes. The fungi of this genus have been shown to be potential sources of new secondary metabolites, which include sesquiterpenoids, diterpenoids, diterpene glycosides, triterpene glycosides, steroids, $\mathrm{N}$-containing 
compounds, aromatic compounds and polyketides, many of which have relevant biological activities for drug discovery, such as cytotoxic, antimalarial and antimicrobial activities. ${ }^{3}$

The genus Colletotrichum is a member of the subdivision Deuteromycotinia of the form order Melanconidiales. The members of this genus cause diseases in a large number of host plants, but they are also frequently encountered as endophytes of tropical woody plants and of herbaceous and monocotyledonous plants. ${ }^{4}$ From the Colletotrichum genus, many bioactive compounds have been isolated, including aspergillomarasmin $\mathrm{A}$ and $\mathrm{B}$, gloeosporone, ferricrocin, colletotric acid, colletochlorins A-D. ${ }^{5}$ However, the secondary metabolites from $C$. crassipes are not reported.
Herein, we report the isolation, structural elucidation, and biological activities (antioxidant, antifungal and acetylcholinesterase inhibition) of the new compound 1-phenylethyl- $O-\alpha$ - $L$-rhamnopyranoside (1) isolated from $C$. crassipes, together with eight known diketopiperazines 2-9, $N$-(2-phenylethyl) acetamide (10) and tyrosol (11), which are secondary metabolites isolated for the first time from this endophyte (Figure 1). Furthermore, we described six compounds that were isolated from Xylaria sp.: griseofulvin (12), dechlorogriseofulvin (14), cytochalasin B (13), cytochalasin C (15), cytochalasin D (16), and 5-carboxy6-hydroxy-3-methyl-3,4-dihydroisocoumarin (17) (Figure 2).<smiles>C[C@@H]1OC(OCCc2ccccc2)=C(O)[C@@H](O)[C@@H]1O</smiles><smiles>CC(C)[C@H]1NC(=O)[C@H](Cc2ccc(O)cc2)NC1=O</smiles><smiles>[R2]C1C[C@H]2C(=O)N[C@@H]([R7])C(=O)N2C1</smiles><smiles>[R3]C[C@H]1NC(=O)[C@@H]2CCCN2C1=O</smiles><smiles>[R4]CCc1ccc([R5])cc1</smiles>

$$
\begin{array}{ll}
2 \mathrm{R}_{1}=\mathrm{CH}\left(\mathrm{CH}_{3}\right)_{2}, \mathrm{R}_{2}=\mathrm{H} & \mathbf{3} \mathrm{R}_{3}=p \mathrm{PhOH} \\
\mathbf{5} \mathrm{R}_{1}=\mathrm{CH}\left(\mathrm{CH}_{3}\right) \mathrm{CH}_{2} \mathrm{CH}_{3}, \mathrm{R}_{2}=\mathrm{OH} & 6 \mathrm{R}_{3}=\mathrm{CH}\left(\mathrm{CH}_{3}\right)_{2} \\
\mathbf{7} \mathrm{R}_{1}=\mathrm{CH}\left(\mathrm{CH}_{3}\right) \mathrm{CH}_{2} \mathrm{CH}_{3}, \mathrm{R}_{2}=\mathrm{H} & 9 \mathrm{R}_{3}=\mathrm{Ph} \\
\mathbf{8} \mathrm{R}_{1}=\mathrm{CH}_{2} \mathrm{Ph}, \mathrm{R}_{2}=\mathrm{H} &
\end{array}
$$

Figure 1. Structure of isolated compounds (1-11) from Colletotrichum crassipes.<smiles></smiles>

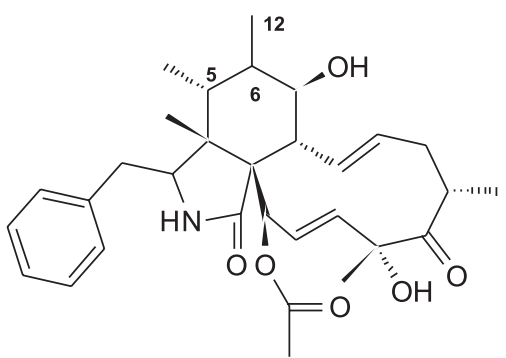

15 Insaturation 6-12

16 insaturation 5-6

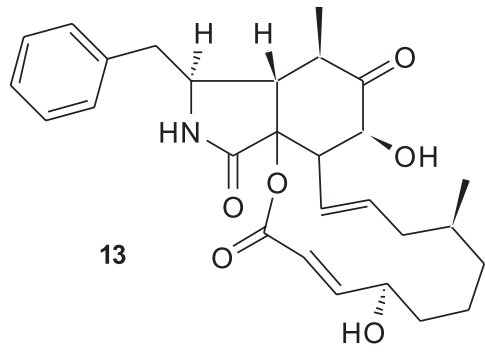<smiles>CC1Cc2c(ccc(O)c2C(=O)O)C(=O)O1</smiles>

Figure 2. Structure of isolated compounds (12-17) from Xylaria sp. 


\section{Experimental}

\section{General experimental procedures}

The structures of the compounds were elucidated using high-resolution electrospray ionization mass spectrometry (HRESIMS) and nuclear magnetic resonance (NMR) analysis. The mass spectra were obtained using a Bruker ultrOTOF-Q-ESI-TOF (configuration orthogonal time-offlight equipment with quadrupole mass filter and collision cell, electrospray ionization and time-of-flight as detector) mass spectrometer (cone voltage $25 \mathrm{~V}) .{ }^{1} \mathrm{H} \mathrm{NMR}(500 \mathrm{MHz})$, ${ }^{13} \mathrm{C}$ NMR (125 MHz) and two-dimensional NMR experiments were acquired using a Varian DRX-500 spectrometer with the non-deuterated residual solvent signal as a reference. ${ }^{1} \mathrm{H}$ NMR $(600 \mathrm{MHz}),{ }^{13} \mathrm{C} \mathrm{NMR}$ $(150 \mathrm{MHz})$ and two-dimensional NMR experiments were acquired using a Bruker Avance III HD 600 spectrometer with the non-deuterated residual solvent signal as a reference. Column chromatography (CC) was performed using silica gel (Merck) and $\mathrm{C}_{18}$ silica gel (Merck). Thin layer chromatography (TLC) analysis were performed using Merck silica gel 60 (230 mesh) and precoated silica gel $60 \mathrm{PF}_{254}$. Spots on TLC plates were visualized under UV light and by spraying with anisaldehyde- $\mathrm{H}_{2} \mathrm{SO}_{4}$ reagent followed by heating at $100{ }^{\circ} \mathrm{C}$. Preparative high performance liquid chromatography (HPLC) was performed on a Varian Pro Star coupled with an ultraviolet photodiode array (UV/PDA) detector using a C18 preparative column $(250 \times 2.0 \mathrm{~mm})$. Analytical HPLC-UV/PDA was performed on a Varian Pro Star (Solvent Delivery Module 240 and Auto Sampler 410) with a C-18 column (Phenomenex Luna, $250.0 \times 4.6 \mathrm{~mm}, 5 \mu \mathrm{m}$ ).

Isolation and identification of the endophytic fungi

Casearia sylvestris leaves were collected in the Experimental Ecological Station of Mogi Guaçu, São Paulo State, Brazil, in April 2004. A voucher specimen was deposited at the Institute of Botany Herbarium in São Paulo, Brazil, with the reference numbers AGS04. The plant material was identified by Dr Inês Cordeiro (Instituto Botânico do Estado de São Paulo, São Paulo, Brazil).

The endophytic fungi were isolated from the leaves of C. sylvestris, which were subjected to surface sterilization. First, the leaves were washed with $\mathrm{H}_{2} \mathrm{O}$ and soap; then, they were immersed in $1 \%$ aqueous sodium hypochlorite solution for $5 \mathrm{~min}$ and $70 \%$ aqueous $\mathrm{EtOH}$ for $1 \mathrm{~min}$. Finally, the vegetal material was immersed in sterile $\mathrm{H}_{2} \mathrm{O}$ for $10 \mathrm{~min}$. The sterilized material was cut into $2 \times 2 \mathrm{~cm}$ pieces and deposited onto a Petri dish that contained potato dextrose agar (PDA) and gentamicin sulfate $\left(50 \mu \mathrm{g} \mathrm{mL}^{-1}\right)$. Pure fungi strains were obtained after serial transfers on PDA plates. ${ }^{6}$ Two endophytes were identified as Xylaria sp. and C. crassipes by Prof Ludwig H. Pfenning using morphological analyses at the Department of Phytopathology, Lavras Federal University, Brazil. Colletotrichum crassipes and Xylaria sp. were deposited in the NuBBE collection as CSY-03 and CSY-02, respectively.

\section{Fungal growth and extraction}

The endophytic fungus $C$. crassipes was cultured on a larger scale by inoculation in $6.0 \mathrm{~L}$ of potato dextrose broth (PDB) medium at $25^{\circ} \mathrm{C}$ on rotary shaker at $120 \mathrm{rpm}$ for 28 days. The flask-accumulated mycelial biomass was separated from the aqueous medium by filtration, and the filtrate was subjected to liquid-liquid partition with ethyl acetate (EtOAc; $3 \times 3 \mathrm{~L}$ ). The EtOAc fraction was evaporated, which resulted in the crude EtOAc extract A. The $C$. crassipes was cultured in $750 \mathrm{~mL}$ of PDB medium at $25{ }^{\circ} \mathrm{C}$ on rotary shaker at $180 \mathrm{rpm}$ during 3 days. Then, $150 \mathrm{ppm}$ of 4-ethylcycloexanone (97\%, Aldrich, density $0.916 \mathrm{~g} \mathrm{~mL}^{-1}$ ) was added, and the fermentation continued for another 10 days on rotary shaker at $150 \mathrm{rpm}$. The mycelial biomass was separated and fractionated as previously described to yield the crude EtOAc extract B.

The endophyte Xylaria sp. was cultivated in two Erlenmeyer flasks (500 mL), each of which contained $90 \mathrm{~g}$ of corn and $75 \mathrm{~mL}$ of $\mathrm{H}_{2} \mathrm{O}$. The medium was autoclaved four times on four consecutive days at $121{ }^{\circ} \mathrm{C}$ for $40 \mathrm{~min}$. After sterilization, the medium was inoculated with the endophyte and incubated by stationary method at $24{ }^{\circ} \mathrm{C}$ for 28 days. At the end of the incubation period, the cultures were combined, ground and extracted with $\mathrm{CH}_{3} \mathrm{OH}(6 \times 150 \mathrm{~mL})$. The solvent was evaporated to yield a crude $\mathrm{CH}_{3} \mathrm{OH}$ extract C. Xylaria sp. was also cultured in $400 \mathrm{~mL}$ of PDB medium at $25^{\circ} \mathrm{C}$ on rotary shaker at $120 \mathrm{rpm}$ for 28 days. The mycelial biomass was separated and fractionated as previously described to yield the crude EtOAc extract D.

Isolation and identification of the metabolites

The crude EtOAc extract A $(380.0 \mathrm{mg})$ from C. crassipes, which was obtained from large-scale culture, it was fractionated by $\mathrm{CC}$ over $\mathrm{C}_{18}$ silica gel (Merck) as the stationary phase and eluted with an $\mathrm{H}_{2} \mathrm{O}-\mathrm{CH}_{3} \mathrm{OH}$ gradient (95:05 $\rightarrow$ 0:100) and $\mathrm{CH}_{3} \mathrm{OH}-\mathrm{EtOAc}(50: 50 \rightarrow 0: 100)$, to yield fourteen fractions (AFr1-AFr14).

Fraction AFr7 (12.7 mg) was separated on preparative HPLC using a C-18 (Phenomenex Luna, 250.0 × 21.2 mm, $10 \mu \mathrm{m})$ preparative column. $\mathrm{A} \mathrm{CH}_{3} \mathrm{CN}: \mathrm{CH}_{3} \mathrm{OH}(20: 80 \mathrm{v} / \mathrm{v}$, 
$10 \mathrm{~mL} \min ^{-1}, \lambda_{\max }=214 \mathrm{~nm}$ ) mixture was used as the eluent to yield the new compound $\mathbf{1}(2.0 \mathrm{mg}$, retention time $\left.\left(\mathrm{t}_{\mathrm{R}}\right)=33 \mathrm{~min}\right)$.

Fraction AFr4 (31.0 mg) was separated on a Varian Pro Star (Solvent Delivery Module SDM SD-1) preparative HPLC coupled with a Varian Pro Star UV/Vis 320 detector system using a C-18 (Phenomenex Luna, $250.0 \times 21.2 \mathrm{~mm}$, $10 \mu \mathrm{m})$ preparative column. $\mathrm{A} \mathrm{CH}_{3} \mathrm{CN}: \mathrm{CH}_{3} \mathrm{OH}(10: 90 \mathrm{v} / \mathrm{v}$, $10 \mathrm{~mL} \mathrm{~min}^{-1}, \lambda_{\max }=214 \mathrm{~nm}$ ) mixture was used as the eluent to yield a mixture of compounds 2,3 and $4(7.5 \mathrm{mg}$, $t_{R}=20$ min).

Fraction AFr5 (34.4 mg) was separated on preparative HPLC using a C-18 (Phenomenex Luna, 250.0 $21.2 \mathrm{~mm}$, $10 \mu \mathrm{m})$ preparative column. $\mathrm{A} \mathrm{CH}_{3} \mathrm{CN}: \mathrm{CH}_{3} \mathrm{OH}(12: 88 \mathrm{v} / \mathrm{v}$, $16 \mathrm{~mL} \mathrm{~min}^{-1}, \lambda_{\max }=214 \mathrm{~nm}$ ) mixture was used as the eluent to yield compound $5\left(8.2 \mathrm{mg}, \mathrm{t}_{\mathrm{R}}=23 \mathrm{~min}\right)$ and a mixture of 6 and 7 ( $\left.4.3 \mathrm{mg}, \mathrm{t}_{\mathrm{R}}=29 \mathrm{~min}\right)$.

Fraction AFr6 (32.7 mg) was separated on a Varian Pro Star (Solvent Delivery Module SDM SD-1) preparative HPLC coupled with a Varian Pro Star UV-Vis 320 detector system using a C-18 (Phenomenex Luna, $250.0 \times 21.2 \mathrm{~mm}$, $10 \mu \mathrm{m})$ preparative column. $\mathrm{A} \mathrm{CH}_{3} \mathrm{CN}: \mathrm{CH}_{3} \mathrm{OH}(17: 83 \mathrm{v} / \mathrm{v}$, $10 \mathrm{~mL} \mathrm{~min}^{-1}, \lambda_{\max }=214 \mathrm{~nm}$ ) mixture was used as the eluent to yield compounds 8 ( $\left.2.9 \mathrm{mg}, \mathrm{t}_{\mathrm{R}}=14 \mathrm{~min}\right), \mathbf{9}(10.0 \mathrm{mg}$, $\left.\mathrm{t}_{\mathrm{R}}=19 \mathrm{~min}\right)$ and $\mathbf{1 0}\left(3.3 \mathrm{mg}, \mathrm{t}_{\mathrm{R}}=28 \mathrm{~min}\right)$.

The crude EtOAc extract B $(155.0 \mathrm{mg})$ from $C$. crassipes was fractionated by CC over silica gel (Merck) as the stationary phase and eluted with a Hex-EtOAc gradient $(80: 20 \rightarrow 0: 100)$ and $\mathrm{EtOAc}-\mathrm{CH}_{3} \mathrm{OH}(70: 30 \rightarrow 0: 100)$ to produce eight fractions (BFr1-BFr8). From the fraction $\mathrm{BFr} 2$ was obtained the compound $\mathbf{1 1}(2.5 \mathrm{mg})$.

The crude $\mathrm{MeOH}$ extract $\mathrm{C}$ (10.48 g) from Xylaria sp. was liquid-partitioned with $\mathrm{H}_{2} \mathrm{O}$ and EtOAc $(4 \times 50 \mathrm{~mL})$. The solvent was evaporated to yield the EtOAc fraction $(1.32 \mathrm{~g})$. This fraction was fractionated by $\mathrm{CC}$ over $\mathrm{C}_{18}$ silica gel (Merck) as the stationary phase and eluted with a $\mathrm{H}_{2} \mathrm{O}-\mathrm{CH}_{3} \mathrm{OH}$ gradient $(95: 05 \rightarrow 0: 100)$ to produce ten sub-fractions (CSFr1-10). Sub-fraction CSFr7 was purified by preparative HPLC using reverse-phase $\mathrm{C}_{18}$ and eluted with $\mathrm{MeOH}: \mathrm{H}_{2} \mathrm{O}\left(55: 45 \mathrm{v} / \mathrm{v}, 12.0 \mathrm{~mL} \mathrm{~min}^{-1}\right.$, $\lambda=221 \mathrm{~nm})$ to yield compounds $\mathbf{1 2}\left(4.9 \mathrm{mg}, \mathrm{t}_{\mathrm{R}}=16 \mathrm{~min}\right)$ and $\mathbf{1 3}\left(7.1 \mathrm{mg}, \mathrm{t}_{\mathrm{R}}=23 \mathrm{~min}\right)$. Sub-fraction $\mathrm{SFr} 8$ was purified by preparative HPLC using reverse-phase $\mathrm{C}_{18}$ and eluted with $\mathrm{MeOH}: \mathrm{H}_{2} \mathrm{O}\left(50: 50 \mathrm{v} / \mathrm{v}, 19.0 \mathrm{~mL} \mathrm{~min}^{-1}, \lambda=221 \mathrm{~nm}\right)$ to yield compound $14\left(11.2 \mathrm{mg}, \mathrm{t}_{\mathrm{R}}=22 \mathrm{~min}\right)$.

The crude EtOAc extract D $(180.0 \mathrm{mg})$ from Xylaria sp. was fractionated by $\mathrm{CC}$ over silica gel (Merck) as the stationary phase and eluted with a Hex-EtOAc gradient $(80: 20 \rightarrow 0: 100)$ and $\mathrm{EtOAc}-\mathrm{CH}_{3} \mathrm{OH}(70: 30 \rightarrow 0: 100)$ to produce fifty-four fractions. The fractions were combined based on their TLC profile into 10 sub-fractions
(DSFr1-10). Sub-fraction DSFr5 (10.0 mg) was submitted to purification on CC over silica gel as the stationary phase and eluted with Hex:EtOAc (1:9) to yield compound $\mathbf{1 5}$ $(4.5 \mathrm{mg})$. From sub-fractions DSFr6 $(3.1 \mathrm{mg})$ and DSFr9 (3.0 mg), we obtained compounds $\mathbf{1 6}$ and $\mathbf{1 7}$, respectively.

The compounds isolated as a mixture were identified by NMR experiments, which the data were compared with standards or previously reported literature data.

1-Phenylethyl-O- $\alpha$ - L-rhamnopyranoside (1)

White amorphous solid; UV (MeOH) $\lambda_{\max } / \mathrm{nm} 223$; HRESIMS $m / z 291.1328[\mathrm{M}+\mathrm{Na}]^{+}\left(\right.$calcd. for $\mathrm{C}_{14} \mathrm{H}_{20} \mathrm{O}_{4} \mathrm{Na}$ 291.1208); ${ }^{13} \mathrm{C}$ and ${ }^{1} \mathrm{H}$ NMR (125 and $500 \mathrm{MHz}$, DMSO- $d_{6}$ ) see Table 1.

Table 1. NMR spectroscopic (500 MHz, DMSO- $d_{6}$ ) data for $\mathbf{1}$

\begin{tabular}{lccc}
\hline Position & $\delta_{\mathrm{H}}(J$ in $\mathrm{Hz})$ & $\delta_{\mathrm{C}}$ & HMBC \\
\hline 1 & $3.73(\mathrm{~m})$ & 67.2 & $\mathrm{C}-1^{\prime} / \mathrm{C}-3$ \\
& $3.57(\mathrm{~m})$ & & \\
2 & $2.80(\mathrm{t}, 7.0)$ & 35.4 & $\mathrm{C}^{\prime}{ }^{\prime} / \mathrm{C}-4$ \\
3 & - & 139.0 & - \\
4 and 8 & $7.23(\mathrm{~d}, 7.0)$ & 128.7 & $\mathrm{C}-2 / \mathrm{C}-6$ \\
5 and 7 & $7.27(\mathrm{t}, 7.0)$ & 128.1 & $\mathrm{C}-3 / \mathrm{C} 5$ \\
6 & $7.18(\mathrm{t}, 7.0)$ & 125.9 & $\mathrm{C}-4$ \\
$1^{\prime}$ & $4.55(\mathrm{~d}, 1.5)$ & 99.9 & $\mathrm{C}-3^{\prime} / \mathrm{C}-1$ \\
$2^{\prime}$ & $3.57(\mathrm{~m})$ & 70.4 & - \\
$3^{\prime}$ & $3.36(\mathrm{~m})$ & 70.8 & - \\
$4^{\prime}$ & $3.15(\mathrm{dd}, 3.0$ and 9.5$)$ & 71.9 & - \\
$5^{\prime}$ & $3.26(\mathrm{dd}, 3.0$ and 6.5$)$ & 68.4 & $\mathrm{C}-4^{\prime}$ \\
$6^{\prime}$ & $1.08(\mathrm{~d}, 6.5)$ & 17.7 & $\mathrm{C}-4^{\prime} / \mathrm{C}-5^{\prime}$, \\
OH-2 ${ }^{\prime} / 4$ & 4.65 & - & - \\
OH-3' & 4.46 & - & - \\
\hline
\end{tabular}

HMBC: heteronuclear multiple bond correlation.

\section{$\mathrm{DPPH}^{\circ}$ scavenging capacity assay}

The radical scavenging capacity of the isolated compounds were evaluated from their ability to reduce the radical 2,2-diphenyl-1-picrylhydrazyl (DPPH') by TLC bioautography assay according to the described procedure. ${ }^{7}$ The method used silica gel 60 F254 precoated plates (Merck, Darmstadt, Germany) as the stationary phase and EtOAc:MeOH (7:3) as the mobile phase. The compounds $\left(1.0 \mathrm{mg} \mathrm{mL}^{-1}\right)$ were spotted in form of bands on the plate. An identical procedure was performed with rutin as the positive control. After development, the plates were immersed for $1 \mathrm{~s}$ in $0.2 \%(\mathrm{~m} / \mathrm{v}) \mathrm{DPPH}^{\circ}$ methanolic solution. The compounds with antiradical activity appeared as yellow spots against the purple-blue background. 


\section{Antifungal activity}

The isolated compounds were evaluated against the fungal phytopathogens C. cladosporioides (Fresen.) G. A. de Vries and C. sphaerospermum Penzig. from microbial collection under the culture number CCIBt 140 and CCIBt 491, respectively, at the Botanical Institute of São Paulo, Brazil, according to the reported method. ${ }^{8}$ The pure compounds were applied on pre-coated silica gel TLC plates in different amounts: 100.0, 50.0, 25.0, 10.0, 5.0 and $1.0 \mu \mathrm{g}$. Nystatin was used as a positive control at 10.0, 5.0 and $1.0 \mu \mathrm{g}$. After eluting with EtOAc:MeOH (7:3), the plates were sprayed with the fungi suspension and incubated at $25^{\circ} \mathrm{C}$ for $48 \mathrm{~h}$. The antifungal activities were detected as clear zones on the fungi suspension background.

\section{Acetylcholinesterase (AChE) inhibitory activity}

The acetylcholinesterase (AChE) inhibitory activities of isolated compounds were determined using a TLC bioautographic assay as described. ${ }^{9}$ The compounds were spotted on TLC plates in concentrations of $100-1.0 \mu \mathrm{g} \mathrm{mL}^{-1}$. Galantamine $(1.0 \mu \mathrm{g})$ was used as a positive control. The contents of the plates were developed using EtOAc:MeOH (8:2) as the mobile phase and subsequent drying. Then, the plates were sprayed with an enzyme solution that contained electric eel AChE type V from Sigma-Aldrich (6.66 $\left.\mathrm{U} \mathrm{mL}^{-1}\right)$, thoroughly dried and incubated at $37{ }^{\circ} \mathrm{C}$ for $20 \mathrm{~min}$. The enzyme activity was detected by spraying a solution of $0.25 \%$ naphthyl acetate in ethanol and $0.25 \%$ Fast Blue B salt aqueous solution. Potential AChE inhibitors appeared as clear zones on the purple-colored background.

\section{Results and Discussion}

The chemical investigation of the $C$. crassipes and Xylaria sp., which were isolated from the leaves of C. sylvestris, yielded seventeen compounds. The molecular structures of all isolated metabolites were elucidated based on the interpretation of their 1D- and 2D-NMR spectra and high-resolution mass spectrometry (HRMS) analysis, which were compared with standards or previously reported literature data.

Compound $\mathbf{1}$ was isolated as an amorphous solid. The (+)-HRESIMS spectrum of $\mathbf{1}$ had an $[\mathrm{M}+\mathrm{Na}]^{+}$ion at $m / z$ 291.1328, which established a molecular formula of $\mathrm{C}_{14} \mathrm{H}_{20} \mathrm{O}_{5}$, requiring five unsaturation equivalents. The ${ }^{13} \mathrm{C}$ NMR data of $\mathbf{1}$ (Table 1) contained six aromatic carbons, two methylenes including one oxygenated
$\left(\delta_{\mathrm{C}} 67.2\right)$, five oxymethines carbons and one methyl group. The analysis of the ${ }^{1} \mathrm{H}$ NMR spectrum shows the aromatic signals at $\delta_{\mathrm{H}} 7.23(2 \mathrm{H}, \mathrm{H}-4 / 8), \delta_{\mathrm{H}} 7.27(2 \mathrm{H}$, $\mathrm{H}-5 / 7)$ and $\delta_{\mathrm{H}} 7.18(1 \mathrm{H}, \mathrm{H}-6)$, which are assigned to monosubstituted aromatic rings. In the ${ }^{1} \mathrm{H}-{ }^{1} \mathrm{H}$ correlation spectroscopy (COSY) experiment the benzylic $\mathrm{H}-2$ $\left(\delta_{\mathrm{H}} 2.80, \mathrm{t}, J 7.0 \mathrm{~Hz}, 2 \mathrm{H}\right)$ proton signals were coupled to the diastereotopic hydrogen $\mathrm{H}-1\left(\delta_{\mathrm{H}} 3.57, \mathrm{~m} ; 3.73, \mathrm{~m}\right.$, $2 \mathrm{H})$. With the heteronuclear multiple bond correlations (HMBC) correlations from the methylene $\mathrm{H}-2$ resonances to $\mathrm{C}-1$ and the two aromatic resonances that were assigned to $\mathrm{C}-3$ and $\mathrm{C}-4$ (and $\mathrm{C}-8$ ), we defined the six-membered ring attached to the $-\mathrm{CH}_{2} \mathrm{CH}_{2} \mathrm{O}-$ residue. The ${ }^{1} \mathrm{H}$ and ${ }^{13} \mathrm{C}$ NMR spectral data displayed signals attributed to one sugar units, an $\alpha$ - $L$-rhamnopyranose, which was identified from the anomeric $\mathrm{H}$-atoms $\left(\delta_{\mathrm{H}} 4.55(J 1.5 \mathrm{~Hz}\right.$, C-1')) and anomeric C-atoms $\left(\delta_{\mathrm{C}} 99.9\right)$, and some other characteristic NMR resonances. ${ }^{10,11}$ The ${ }^{1} \mathrm{H}-{ }^{1} \mathrm{H}$ COSY correlations and total correlation spectroscopy (TOCSY) $1 \mathrm{D}$ experiment confirm the connectivity of the hydrogens of the $\alpha$ - $L$-rhamnopyranose. In TOCSY $1 D$ experiment irradiation of H-6' $\left(\delta_{\mathrm{H}} 1.08\right)$ resulted in the enhancement of H-5' $\left(\delta_{\mathrm{H}} 3.26\right)$, H-4' $\left(\delta_{\mathrm{H}} 3.15\right), \mathrm{H}-3^{\prime}\left(\delta_{\mathrm{H}} 3.36\right)$, H-2' $\left(\delta_{\mathrm{H}} 3.57\right)$, and low-intensity observed to $\delta_{\mathrm{H}} 4.55$ (H-1'), revealing the correlations of all the hydrogens H-1'/H-2'/H-3'/H-4'/H-5'/H-6'. The signal at 4.65 (s) was assigned to $\mathrm{OH}-2$ '/4' because of the $2 \mathrm{H}$ integration and the absence of correlation in the HMQC (heteronuclear multiple quantum correlation) spectrum.

The $\alpha$ - $L$-rhamnopyranose were attached to $\mathrm{C}-1$ due the HMBC correlation from H-1' $\left(\delta_{\mathrm{H}} 4.55\right)$ to $\mathrm{C}-1$ $\left(\delta_{\mathrm{C}} 67.2\right)$ (Figure 3$)$. Collectively, the planar structure of the compound 1-phenylethyl- $O$ - $\alpha$ - $L$-rhamnopyranoside (1) was determined. The relative configurations for the C-1' until C-5' were established by NOESY (nuclear Overhauser effect spectroscopy) 1D experiment and by couple constant value. All spectra can be found in Supplementary Information section (SI section). Similar compound was isolated from endophytic fungi Xylaria sp. associated with Pinus tabuliformis from China. ${ }^{11}$ The $L$-rhamnopyranose is a component found in different natural bioactive compounds, these derivative compounds has been widely used in the cosmetics and food industry. ${ }^{12}$

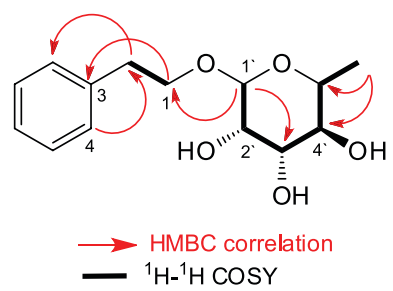

Figure 3. Selected $\mathrm{HMBC}$ correlation and ${ }^{1} \mathrm{H}^{-1} \mathrm{H}$ COSY for $\mathbf{1}$. 
In addition of the new isolated natural product, sixteen known compounds were identified: diketopiperazines $\operatorname{cyclo}(D)-\operatorname{Pro}-(L)-\operatorname{Val}(\mathbf{2}),{ }^{13,14} \operatorname{cyclo}(D)-\operatorname{Pro}-(D)-\operatorname{Tyr}(\mathbf{3}),{ }^{13,15}$ cyclo $(D)$-Val- $(D)$-Tyr $(4),{ }^{16}$ cyclo $(D)$-Hyp- $(L)$-Ile $(5),{ }^{13}$ cyclo $(D)$-Pro- $(D)$-Leu $(6),{ }^{15}$ cyclo $(D)$-Pro- $(L)$-Ile $(7),{ }^{13}$ cyclo $(D)$-Pro- $(L)$-Phe $(\mathbf{8})^{14}$ and cyclo $(D)$-Pro- $(D)$-Phe $(\mathbf{9}) .^{13}$ Together with $N$-(2-phenylethyl) acetamide $(\mathbf{1 0})^{17}$ and tyrosol (11), ${ }^{18}$ which were isolated from endophyte Colletotrichum crassipes. Moreover, the following compounds were isolated from Xylaria sp.: griseofulvin (12), ${ }^{19}$ dechlorogriseofulvin $(\mathbf{1 4}),{ }^{20}$ three known cytochalasins $\mathrm{B}(\mathbf{1 3}),{ }^{19} \mathrm{C}(\mathbf{1 5}){ }^{21}$ and $\mathrm{D}(\mathbf{1 6}),{ }^{19}$ and 5-carboxy6-hydroxy-3-methyl-3,4-dihydroisocoumarin (17).22

The isolated compounds were evaluated for their capacity to scavenge DPPH ${ }^{\bullet}$ radical. TLC bioautography assay was selected because of several advantages, including its flexibility, simplicity and high throughput. ${ }^{23}$ Antioxidant compounds were visualized as yellow spots on the TLC plates. The TLC bioautography profile of the isolated compounds indicated that four compounds $(\mathbf{9}, 12,13$ and 16) showed yellow spots against the purple background. In other words, only compounds $9,12,13$ and 16 exhibited antioxidant capacity at $1 \mathrm{mg} \mathrm{mL}-1$. In the context of a structure-activity relationship, a central feature related to the efficiency of reduction of radical $\mathrm{DPPH}^{*}$ was the need for electron-donating groups. The difference between 12 (active compound) and $\mathbf{1 4}$ (not active) is just the presence of $-\mathrm{Cl}$, which increases the antioxidant capacity of the compound, through the reduction of DPPH. These results demonstrated that the radical scavenging activities were due to direct reduction via electron transfer and/or radical quenching stabilizing the radical DPPH.

The isolated compounds were tested for their antifungal activities against two phytopathogenic fungi (C. cladosporioides and C. sphaerospermum) using the TLC diffusion method. Compounds 9,10 and 17 exhibited high antifungal activities against both fungal strains. These compounds presented potent antifungal activity at $50 \mu \mathrm{g}$ against $C$. cladosporioides and moderate activity against C. sphaerospermum at the same amount. Compounds 9 and 17 exhibited antifungal activity at $10 \mu \mathrm{g}$. The other compounds were inactive at $100 \mu \mathrm{g}$. The bioactive compounds $\mathbf{9}$ and $\mathbf{1 0}$ were previously reported to be antifungal agents. ${ }^{24}$ These microorganisms may produce antifungal metabolites as self-defense or in plant defense against other pathogenic microorganisms.

The compounds were evaluated for their AChE inhibitory activity using TLC bioautography. Among all of the isolated compounds that were tested, only three compounds $(\mathbf{9}, \mathbf{1 3}$ and 15) showed potent $\mathrm{AChE}$ inhibition at $60 \mu \mathrm{g}$. The other compounds showed no significant inhibitory effect.

\section{Conclusions}

Seventeen natural products including a new one were isolated from the two endophytic fungi associated with leaves of Casearia sylvestris, a vegetal species used in Brazilian traditional medicine. The compounds displayed biological activity, the compounds $\mathbf{9 , 1 3}$ and $\mathbf{1 5}$ showed potent AChE inhibition, the compounds 9, 12, 13 and 16 exhibited antioxidant capacity at $1 \mathrm{mg} \mathrm{mL}^{-1}$ and the compounds 9,10 and $\mathbf{1 7}$ exhibited high antifungal activities against both fungal strains tested, C. cladosporioides and C. sphaerospermum. Secondary metabolites that exhibit biological activity must be produced to protect or assist the development of the microorganism or those organisms associated with it as the host species. The studies with endophytic fungi of medicinal plants lead us to obtain unknown metabolites as well as its biological activities, which increases the prospects of using endophytes providing benefits to humanity.

\section{Supplementary Information}

Supplementary information is available free of charge at http://jbcs.sbq.org.br as a PDF file.

\section{Acknowledgments}

We gratefully acknowledge the financial support from FAPESP (Fundação de Amparo à Pesquisa do Estado de São Paulo, as part of Biota-FAPESP, the Biodiversity Virtual Institute Program grant No. 03/02176-7, 2010/52327-5 and 2013/07600-3), CNPq (Conselho Nacional de Desenvolvimento Científico e Tecnológico) and CAPES (Coordenação de Aperfeiçoamento de Pessoal de Nível Superior). M. L. Z. acknowledge FAPESP for the scholarship 2011/03017-6. V. M. C. acknowledge CAPES for the scholarship.

\section{References}

1. Bou, D. D.; Lago, J. H. G.; Figueiredo, C. R.; Matsuo, A. L.; Guadagnin, R. C.; Soares, M. G.; Sartorelli, P.; Molecules 2013, 18, 9477; Joly, A. B.; Botânica: Introdução a Taxonomia Vegetal, 12a ed.; Companhia Editora Nacional: São Paulo, Brasil, 1998; Lorenzi, H.; Matos, F. J. A.; Plantas Medicinais do Brasil: Nativas e Exóticas; Instituto Plantarum: Nova Odessa, Brasil, 2008.

2. Ferreira, P. M.; Costa-Lotufo, L. V.; Moraes, M. O.; Barros, F. W. A.; Martins, A. M. A.; Cavalheiro, A. J.; Bolzani, V. S.; Santos, A. G.; Pessoa, G.; An. Acad. Bras. Cienc. 2011, 83, 1373. 
3. Song, F.; Wu, S.; Xuan, Q.; Wang, T.; Chem. Biodiversity 2014, 11, 673; Kirk, P. M.; Cannon, P. F.; Minter, D. W.; Stalpers, J. A.; Ainsworth \& Bisby's Dictionary of the Fungi, $10^{\text {th }}$ ed.; CABI Publishing: Wallingford, England, 2008.

4. Farr, D. F.; Aime, C.; Rossman, A. Y.; Palm, M. E.; Mycol. Res. 2006, 110, 1395.

5. García-Pajón, C. M.; Collado, I. G.; Nat. Prod. Rep. 2003, 20, 426.

6. Silva, G. H.; Teles, H. L.; Zanardi, L. M.; Young, M. C. M.; Eberlin, M. N.; Haddad, R.; Pfenning, L. H.; Costa-Neto, C.; Castro-Gamboa, I.; Bolzani, V. S.; Araujo, A. R.; Phytochemistry 2006, 67, 1964.

7. Simões-Pires, C. A.; Queiroz, E. F.; Henriques, A. T.; Hostettmann, K.; Phytochem. Anal. 2005, 16, 307.

8. Homans, A. L.; Fuchs, A.; J. Chromatogr. 1970, 51, 327.

9. Marston, A.; Kissling, J.; Hostettmann, K.; Phytochem. Anal. 2002, 13, 51.

10. Disadee, W.; Mahidol, C.; Sahakitpichan, P.; Sitthimonchai, S.; Ruchirawat, S.; Kanchanapoom, T.; Tetrahedron 2011, 67, 4221; Zhao, L.; Cheng, J.; Ao, X.; Ren, B.; Li, W.; Chem. Nat. Compd. 2015, 51, 1103; Sheng-Xiong, H.; Xun, L.; Quan-Jang, N.; Li-Sheng, D.; Shun-Lin, P.; Helv. Chim. Acta 2004, 87, 598.

11. Wang, F.; Han, S.; Hu, S.; Xue, Y.; Wang, J.; Xu, H.; Chen, L.; Zhang, G.; Zhang, Y.; Molecules 2014, 19, 1250.

12. de Winter, K.; Šimcikova, D.; Schalck, B.; Weignerova, L.; Pelantova, H.; Soetaert, W.; Desmet, T.; Kren, V.; Bioresour. Technol. 2013, 147, 640.
13. Fdhila, F.; Vazquez, V.; Sanchez, J. L.; Riguera, R.; J. Nat. Prod. 2003, 66, 1299.

14. Jayatilake, G. S.; Thornton, M. P.; Leonard, A. C.; Grimwade, J. E.; Baker, B. J.; J. Nat. Prod. 1996, 59, 293.

15. Wang, Y.; Mueller, U. G.; Clardy, J.; J. Chem. Ecol. 1999, 25 , 935.

16. Stark, T.; Hofmann, T.; J. Agric. Food Chem. 2005, 53, 7222.

17. Maskey, R. P.; Asolkar, R. N.; Kapaun, E.; Wagner-Dobler, I.; Laatsch, H.; J. Antibiot. 2005, 55, 643.

18. Chen, H.; Fujita, M.; Feng, Q.; Clardy, J.; Fink, G. R.; Proc. Natl. Acad. Sci. U. S. A. 2004, 101, 5048.

19. Cafêu, M. C.; Silva, G. H.; Teles, H. L.; Araujo, A. R.; Bolzani, V. S.; Young, M. C. M.; Pfenning, L. H.; Quim. Nova 2005, 28, 991.

20. Park, J. H.; Choi, G. L.; Lee, H. B.; Kim, K. M.; Jungs, H. S.; Lee, S. W.; Jang, K. S.; Cho, K. Y.; Kim, J. C.; J. Microbiol. Biotechnol. 2005, 15, 112.

21. Espada, A.; Rivera-Sagredo, A.; Fuente, J. M.; HuesoRodriguez, J. A.; Elson, S. W.; Tetrahedron 1997, 53, 6485.

22. Anderson, J. R.; Edwards, R. L.; Whalley, A. J. S.; J. Chem. Soc. Perkin Trans. 1983, 9, 2185.

23. Simões-Pires, C. A.; Queiroz, E. F.; Henriques, A. T.; Hostettmann, K.; Phytochem. Anal. 2005, 16, 307.

24. Collado, I. G.; Aleu, J.; J. Mol. Catal. B: Enzym. 2001, 13, 77.

Submitted: September 19, 2017 Published online: March 9, 2018 